\title{
Rosids - Reproductive structures, fossil and extant, and their bearing on deep relationships: Introduction
}

\author{
P. K. Endress ${ }^{1}$ and E. M. Friis ${ }^{2}$ \\ ${ }^{1}$ Institute of Systematic Botany, University of Zurich, Zurich, Switzerland \\ ${ }^{2}$ Dept. of Palaeobotany, Swedish Museum of Natural History, Stockholm, Sweden
}

As a consequence of the rapid and successful progress of phylogenetics in the past decade, there is an increasing imbalance between our insight on phylogenetic relationships and the evolution of structure and biology of angiosperms. However important a continuous improvement of resolution of the phylogenetic tree of angiosperms is, it remains of limited use if the structure and biology of the newly recognized clades are not studied concomitantly.

In addition, despite the phylogenetic advances, the relationships between many large clades are still not well resolved. This is particularly true for the relationships between the orders of rosids (Judd and Olmstead 2004, Soltis et al. 2005, Sytsma 2005). Thus straightforward comparative structural studies are hampered by such uncertainties. Nevertheless, to avoid a vacuum we should not hesitate to build on the available new fundament, even if it is still shaky at some places.

In such comparative approaches the structure of extant and fossil plants should be studied in an integrative way (Friis and Endress 1990, Endress and Friis 1994, Zimmer et al. 2000, Schönenberger et al. 2001, Doyle et al. 2003, Friis et al. 2006). Anatomical techniques developed on extant plants can also be used for charcoalified fossil plants. These techniques allow not only anatomical and histological studies in fossils but also a morphological reconstruction of the outer and inner surfaces of the organs in flowers (Schönenberger et al. 2001, Friis et al. 2003, Schönenberger 2005).

Rosids are one of the largest clades of the flowering plants. Molecular systematics has identified a number of larger monophyletic components at the order level, some with the same circumscription as in traditional classifications, others with new and unexpected associations of families or family clusters. Yet the relationships between the orders, i.e. deep relationships, are not well resolved. Numerous fossil flowers, fruits and seeds recovered from Late Cretaceous floras over the past 25 years are crucial for the recognition of deep relationships. Among Late Cretaceous rosids, taxa related to Saxifragales, Fagales, and Rosales are particularly common (e.g. Crane et al. 2004, Crepet et al. 2004, Friis et al. 2005), but most of the enormous diversity of Late Cretaceous reproductive structures remains to be studied. Based on our current knowledge it is clear that many extant lineages were well 
established in the Late Cretaceous floras cooccurring with many extinct groups (e.g. Friis et al. 2006). Unusual structural features in flowers of larger clades may have shared underlying patterns that are synapomorphies for these clades (e.g. the androecium in Malvales). However, such underlying patterns often have not been worked out in detail and need critical comparative studies. Comparison of reproductive structures among extant groups and fossils of rosids will also be an important component in unravelling their evolutionary history. Exceptional groups with a rich fossil record but perhaps no direct extant descendents need to be compared among themselves and with the putative closest extant relatives (e.g. Normapolles pollen with floral fossils and with extant Fagales).

For the interpretation of fossil flowers knowledge on the structure and biology of extant flowers is necessary. Vice versa, fossil flowers, if correctly interpreted, are not only crucial for calibration of evolutionary events, as are fossils in general, but can reveal information on the past diversity and evolution of extant reproductive structures.

The following publications are essentially the contributions to a Symposium on Rosids Reproductive structures, fossil and extant, and their bearing on deep relationships, which was held at the XVII International Botanical Congress, Vienna, in July 2005. The symposium intended to include and, if possible, integrate fossil and extant reproductive structures of rosids and to advance our knowledge on morphology and relationships and evolution within larger clades of rosids.

Schönenberger and von Balthazar (2006) give an introduction and overview of the current state of knowledge of extant and fossil rosid reproductive structures in the framework of phylogeny and evolution. Friis et al. (2006) provide a review and new aspects on the extinct Normapolles group (Fagales), which played an important role in the Late Cretaceous and Early Cainozoic flora and vegetation of Europe, with special emphasis on the coordination of isolated pollen with floral structures. Hermsen et al. (2006) discuss the evolution of reproductive structures of Saxifragales based on phylogenetic studies including fossil data. Von Balthazar et al. (2006) provide new aspects for floral development and evolution in extant Malvales, with a focus on the Malvatheca clade of Malvaceae s.l. Matthews and Endress (2006) trace the distribution of a new systematic feature in rosid flowers, specialized mucilage cells, and compare the characterization of new clades within four rosid orders by floral structural features. Finally, Endress and Matthews (2006) make first steps towards a floral structural characterization of the new supraordinal clades of rosids as found recently in molecular phylogenetic studies by other authors. A symposium contribution by $\mathrm{P}$. Herendeen who used the fossil record of legumes to test evolutionary and biogeographic hypotheses is here not included.

We hope that this collection of publications on structural features of rosids will catalyze new studies on the structural and evolutionary understanding of rosids and their component clades and also of other large angiosperm groups.

\section{References}

von Balthazar M., Schönenberger J., Alverson W. S., Janka H., Bayer C., Baum D. A. (2006) Structure and evolution of the androecium in the Malvatheca clade (Malvaceae s.1.) and implications for Malvaceae and Malvales. Pl. Syst. Evol. 260: 171-197.

Crane P. R., Herendeen P., Friis E. M. (2004) Fossils and plant phylogeny. Amer. J. Bot. 91: 1683-1699.

Crepet W. L., Nixon K. C., Gandolfo M. A. (2004) Fossil evidence and phylogeny: the age of major angiosperm clades based on mesofossil and macrofossil evidence from Cretaceous deposits. Amer. J. Bot. 91: 1666-1682.

Doyle J. A., Eklund H., Herendeen P. S. (2003) Floral evolution in Chloranthaceae: implications of a morphological phylogenetic analysis. Int. J. Pl. Sci. 164 (5, Suppl.): S365-S382. 
Endress P. K., Friis E. M. (eds.) (1994) Early evolution of flowers. Pl. Syst. Evol. Suppl. 8: 1229.

Endress P. K., Matthews M. L. (2006) First steps towards a floral structural characterization of the major rosid subclades. Pl. Syst. Evol. 260: $223-251$.

Friis E. M., Endress P. K. (1990) Origin and evolution of angiosperm flowers. Adv. Bot. Res. 17: 99-162.

Friis E. M., Pedersen K. R., Schönenberger J. (2003) Endressianthus, a new Normapollesproducing plant genus of fagalean affinity from the Late Creataceous of Portugal. Int. J. Pl. Sci. 164 (Supplement), S201-S223.

Friis E. M., Pedersen K. R., Crane P. R. (2005) When Earth started blooming: insights from the fossil record. Curr. Opin. Pl. Biol. 8: 5-12.

Friis E. M., Pedersen K. R., Crane P. R. (2006) Cretaceous angiosperm flowers: innovation and evolution in plant reproduction. Palaeogeogr., Palaeoclimatol., Palaeoecol. 232: 251-293.

Friis E. M., Pedersen K. R., Schönenberger J. (2006) Normapolles plants: a prominent component of the Cretaceous rosid diversification. Pl. Syst. Evol. 260: 107-140.

Hermsen E. J., Nixon K. C., Crepet W. L. (2006) Fossil reproductive structures of Saxifragales and saxifrage evolution. Pl. Syst. Evol. 260: 141169.

Judd W. S., Olmstead R. G. (2004) A survey of tricolpate (eudicot) phylogenetic relationships. Amer. J. Bot. 91: 1627-1644.

Matthews M. L., Endress P. K. (2006) Floral structure and systematics in four orders of rosids, including a broad survey of floral mucilage cells. Pl. Syst. Evol. 260: 199-221.

Schönenberger J. (2005) Rise from the ashes reconstruction of charcoal fossil flowers. Trends Pl. Sci. 10: 436-443.

Schönenberger J., von Balthazar M. (2006) Reproductive structures and phylogenetic framework of the rosids - progress and prospects. Pl. Syst. Evol. 260: 87-106.

Schönenberger J., Friis E. M., Matthews M. L., Endress P. K. (2001) Cunoniaceae in the Cretaceous of Europe: evidence from fossil flowers. Ann. Bot. 88: 439-455.

Soltis D. E., Soltis P. S., Endress P. K., Chase M. W. (2005) Phylogeny and evolution of angiosperms. Sinauer, Sunderland, MA.

Sytsma K. J., Hall J. (2005) Rosid angiosperms: circumscription, issues, and systematic advances. XVII International Botanical Congress, Vienna. Abstract 5.8.3., pp. 84-85.

Zimmer E. A., Qiu Y.-L., Endress P. K., Friis E. M. (eds.) (2000) Current perspectives on basal angiosperms. Int. J. P1. Sci. 161 (Suppl. 6): S1S248.

Addresses of the authors: Peter K. Endress (e-mail: pendress@systbot.unizh.ch), Institute of Systematic Botany, University of Zurich, Zollikerstrasse 107, 8008 Zurich, Switzerland. Else Marie Friis, Dept. of Palaeobotany, Swedish Museum of Natural History, Box 50007, 10405 Stockholm, Sweden. 